УДК 331.101.03: 65.01

\title{
ОРГАНІЗАЦІЙНІ АСПЕКТИ СТВОРЕННЯ СИСТЕМИ МОТИВАЦІЇ НА ПІДПРИЕМСТВІ
}

К-т екон. наук О.В.Громова, магістрант С.О. Носик

\section{ОРГАНИЗАЦИОННЫЕ АСПЕКТЫ СОЗДАНИЯ СИСТЕМЫ МОТИВАЦИИ НА ПРЕДПРИЯТИИ}

К-т.экон.наук Е.В.Громова, магистрант С.А.Носик

ORGANIZATIONAL ASPECTS OF CREATION OF MOTIVATION FOR THE ENTERPRISE

Cand. of econ. sciences E.V.Gromova, master student S.O.Nosik

Стаття присвячена вирішенню проблем пошуку моделі стимулювання мотивачії персоналу та удосконалення процесу праці на підприємстві. Доведена роль важливості вибору мотиваційної моделі поведінки. Були запропоновані деякі заходи, щуодо координації дій керівника, необхідні для найбільи ефективної мотивації прачівників $i$ забезпечення оптимального рівня якості виконання ними роботи, при обліку необхідності задоволення їхніх потреб.

Ключові слова: мотивачуі, персонал, мотиваційні теорії, фактори мотивації, трудова мотивачія, модель поведінки.

The article is devoted to solving problems of finding models to stimulate staff motivation and improvement process in the enterprise. Proved the importance of the role of choice motivational behavior. In Ukraine, the concept of work motivation in economic terms appeared recently in connection with the democratization of production. Previously, it was used mainly in industrial economic sociology, pedagogy, psychology. Were proposed some measures on coordination manager needed to most effectively motivate employees and ensure the optimal level quality of performance of the work, taking into account the need to meet their needs. Motivational aspects of labor management have been widely used in advanced market economies. During the study identified the needs of workers and their desire, satisfaction of which contribute to their successful work. With proper organization of incentives likely to increase labor productivity, and as a result the organization can rise to a higher level of development.

Keywords: motivation, staff motivation theory, motivation factors, work motivation, behavior model.

Статья посвящена решению проблем поиска модели стимулирования мотивации персонала и усовершенствования прочесса труда на предприятии.

Доказана роль важности выбора мотивационной модели поведения. Были предложены некоторые меры, по координации действий руководителя, необходимые для наиболее эффективной мотивачии работников и обеспечение оптимального уровня качества выполнения ими работы, при учете необходимости удовлетворения их потребностей.

Ключевье слова: мотивачия, персонал, мотивачиионные теории, факторь мотивации, трудовая мотивация, модель поведения.

Вступ.

У сучасному менеджменті все більшого значення набувають мотиваційні чинники. Основна мета процесу мотивації - це отримання максимальної віддачі від використання наявних трудових ресурсів, що дозволяє підвищити загальну 
результативність і прибутковість діяльності підприємства.

В світі, де кожен день на шляху компанії або організації зустрічається безліч конкурентів, де, щоб домогтися успіху, потрібно, йти в ногу 3 часом, роль менеджменту воістину значна, адже суть менеджменту в тому, щоб домогтися кінцевого результату діяльності організації 3 максимальною віддачею на кожному етапі процесу управління і мінімальними витратами.

Постановка проблеми у загальному вигляді та іï зв'язок із науковими та практичними завданнями.

Еволюція застосування різних методів мотивації показала як позитивні, так i негативні аспекти їхнього застосування, i це природний процес, тому що в теорії i практиці управління немає ідеальної моделі стимулювання, яка відповідала б різноманітним вимогам. Існуючі моделі мотивації дуже різні за своєю спрямованістю й ефективністю.

Завжди існувало багато проблем пов'язаних 3 політикою мотивації: проблема взаємовідносин з керівництвом, незадоволеність розміром заробітної плати, умовами побуту та праці в цілому на підприємстві. Головною перешкодою на шляху вирішення цих питань - небажання управлінського персоналу замислюватися про умови життя i праці людей, які безпосередньо створюють прибуток. У ринкових умовах слід приділяти особливу увагу нематеріального стимулюванню, створюючи гнучку систему пільг для працівника.

Актуальність проблем мотивації не оскаржується ні наукою, ні практикою, оскільки від чіткої розробки ефективної системи мотивації залежить не тільки підвищення соціальної і творчої активності конкретного працівника (менеджера, робітника), але і кінцеві результати діяльності підприємств.

Аналіз останніх досліджень i публікацій.

Проблеми мотивації персоналу цікавили вчених протягом усієї історії економічної науки. Питаннями мотивації праці займалися як закордонні, так i вітчизняні автори, зокрема: А.Маслоу, Д.Мак-Грегор, П. Армстронг, А.Кібанов, І.Баткаєва, О.Мітрофанова, М.Ловчева, Ф.Херцберг, Б.Моснер, Б.Снідерман та інші.

У процесі історичного розвитку мотивація як економічна категорія пройшла два етапи:

- застосування політики «батога та пряника»;

- використання методів психології і фізіології.

Суттєвий внесок у розвиток теорій мотивації зробили українські вчені. Так, вчений М.Вольський[2] вважав необхідним поліпшувати фізичні, моральні та інтелектуальні умови існування людини, наголошуючи, що політекономія $\epsilon$ наукою про діяльність людини, спрямовану на задоволення матеріальних $\mathrm{i}$ духовних потреб. Економіст М.Туган-Барановський одним із перших у світі розробив чітку класифікацію потреб[1]. Однак, деякі питання щодо визначення основних мотиваторів персоналу сучасних українських підприємств потребують подальшого системного вивчення

\section{Визначення мети та задачі} дослідження.

Метою дослідження $є$ розробка науково-обгрунтованих рекомендацій щодо удосконалення системи мотивації i організації праці на підприємстві. Досягнення цієї мети потребує вирішення низки завдань, а саме:

вивчення теоретичних основ мотивації трудової діяльності та iï вплив на підвищення ефективності діяльності організації;

- аналіз ролі і значення стимулювання праці в підвищенні ефективності діяльності організації;

- аналіз мотивації трудової діяльності на підприємстві;

- виявлення взаємозв'язків мотивації праці та ефективності діяльності організації;

- визначення шляхів вдосконалення організації праці та мотивації трудової діяльності персоналу.

Для досягнення визначеної мети i завдань у роботі було використано 
загальнонаукові і спеціальні методи дослідження: принципи системного динамічного й процесного підходів та методи якісного аналізу i синтезу при уточненні категорії «конкурентна перевага підприємства» та ознак класифікації видів конкурентних переваг.

\section{Основна частина дослідження.}

Мотиваційні аспекти управління працею набули широкого застосування в країнах з розвиненою ринковою економікою. У нашій країні поняття мотивації праці в економічному сенсі з'явилося порівняно недавно у зв'язку 3 демократизацією виробництва. Раніше воно вживалося, в основному, у промисловій економічній соціології, педагогіці, психології.

Це негативно впливало на мотиваційну особистість працівника, не викликало зацікавленості у власному розвитку, самовдосконаленні, але ж саме ця система сьогодні є найважливішим резервом підвищення ефективності виробництва.

Трудова мотивація - це процес стимулювання окремого виконавця або групи людей до діяльності, спрямований на досягнення цілей організації, до продуктивної виконання прийнятих рішень або намічених робіт [3]

Усі теорії мотивації поділяють на змістові та процесуальні. Змістовні теорії мотивації базуються на потребах та пов'язаних з ними чинниках, що визначають поведінку людей. Процесуальні теорії розглядають теорію в іншому плані. У них аналізується те, як людина розподіляє зусилля для досягнення різних цілей, і як вибирає конкретний вид поведінки. Процесуальні теорії не заперечують існування потреб, але вважають, що поведінка людей визначається не тільки ними. Згідно процесуальним теоріям, поведінка особистості є також функцією його сприйняття і очікувань, пов'язаних 3 даною ситуацією, i можливих наслідків обраного ними типу поведінки.

Для управління працею на основі мотивації необхідно виявити схильності та інтереси працівника 3 урахуванням його персональних та професійних здібностей. Необхідно повніше використовувати особисті цілі учасників трудового процесу і цілі організації.

Ніякі встановлені завдання не викликають зацікавленості людини в активізації своїх зусиль до тих пір, поки вони не перетворяться на його «внутрішню» мету і далі в його «внутрішній» план дії. Тому для кінцевого успіху велике значення має збіг цілей працівника і підприємства.

Мотивацію як процес, можна представити у вигляді ряду послідовних етапів розглянутих на рисунку 1.1 [ 4].

Дуже непросто виявити, які мотиви $€$ вирішальними в мотиваційному процесі конкретної людини в конкретних умовах.

Мотивація як функція управління реалізується через систему стимулів, тобто будь-які дії підлеглого повинні мати для нього позитивні або негативні наслідки 3 точки зору задоволення його потреб або досягнення його цілей. Вивчення колективу може дозволити керівнику створити мотиваційну структуру, за допомогою якої він здійснить виховання колективу в потрібному напрямку.

Таким чином, слід зазначити, що шлях до ефективного управління персоналом лежить через розуміння його мотивації. Тільки знаючи, що рухає людиною, що спонукає іiі до дій, які мотиви лежать в основі його поведінки, можна спробувати розробити ефективну систему форм і методів управління людиною. Для цього необхідно знати, як виникають ті чи інші мотиви, як i якими способами, мотиви можуть бути приведені в дію , як здійснюється мотивування людей.

$\begin{array}{crr}\text { Також } & \text { необхідно } & \text { знати, що } \\ \text { основними } & \text { складовими } & \text { ефективного }\end{array}$ стимулювання праці $є$ стимулювання трудящої людини. На підприємствах, де люди тісно взаємодіють один $з$ одним, при використанні стимулів повинні враховуватися потреби та їх задоволення, підприємливість і інтереси особистості, і навіть характер i спосіб життя. Тоді стимулювання буде по-справжньому дієвим i значущим.

До числа найбільш простих і широко поширених (класичних) теорій мотивації праці, в основі яких лежить специфічна 
картина людини, належить концепція свідомості та мотивації працівників. професора Мічиганського університету Менеджери повинні прагнути розвивати Дугласа МакГрегора, яка зветься «ХУ - групу, якщо вона недостатньо мотивована, теорією». Ця концепція включає дві від стану «Х» до стану «У. У цілому в протилежні теорії: теорію «Х» і теорію «У». поглядах сучасних фахівців і менеджерів на Згідно рекомендації МакГрегора, «ХУ - працівника переважають установки теорії теорію» необхідно використовувати, «У». враховуючи конкретний стан рівня

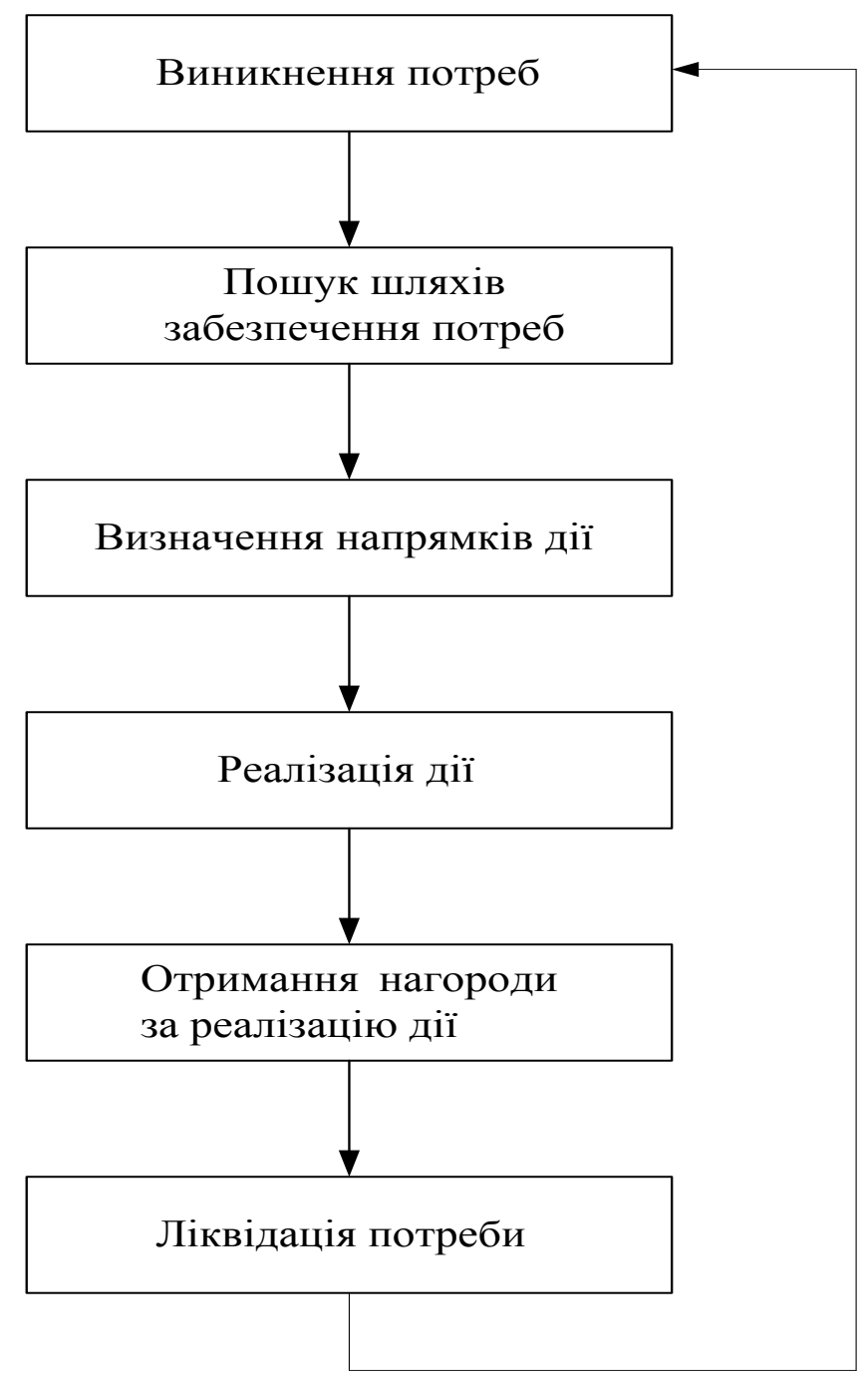

Рисунок 1.1 - Схема мотиваційного процесу

Величезний внесок у розвиток теорії мотивації вніс Абрахам Маслоу (1908-1970), американський психолог, один з лідерів так званої гуманістичної психології.

У кожний конкретний момент часу людина буде прагнути до задоволення тієї потреби, що для неї $\epsilon$ важливішою або сильною.

Фізіологічні потреби (потреби найнижчого рівня) $є$ необхідними для виживання. Вони включають потребу в їжі, воді, захисті, відпочинку, сексуальні потреби.
Потреби в безпеці включають потреби в захисті від фізичних i психологічних небезпек 3 боку навколишнього світу i впевненість у тому, що фізіологічні потреби будуть задовольнятися в майбутньому (покупка страхового полісу або пошук надійної роботи 3 гарними видами на пенсію).

Соціальні потреби (потреби в приналежності, дружбі, любові) включають почуття приналежності до чого-небудь або кого-небудь, підтримки. 
Потреби в повазі включають потреби в особистих досягненнях, компетентності, повазі з боку оточуючих, визнанні.

Потреби в самовираженні, самореалізації - потреби в реалізації своїх потенційних можливостей i зростанні як особистості.

Спочатку споживачі прагнуть задовольнити потреби нижчого рівня, потім можуть думати про задоволення наступної за значимістю потреби. Основний недолік теорії Маслоу зводиться до того, що їй не вдалося врахувати індивідуальні відмінності людей. Виходячи 3 минулого досвіду, одна людина може бути найбільше зацікавлена у самовираженні, у той час як поведінка іншої буде в першу чергу визначатися потребою у визнанні, соціальними потребами.

Теорія Герцберга — це природнє продовження теорії Маслоу: мотиватори сконцентровані на верхніх рівнях ієрархії потреб Маслоу, тоді як гігієнічні фактори являють собою потреби нижніх рівнів.

До мотиваторів Герцберг відніс [5]:

- досягнення;

- визнання успіху;

- інтерес до роботи як такий;

- відповідальність;

- можливість професійного зростання.

До чинників(факторів) контексту

Герцберг відніс:

- спосіб управління;

- політику адміністрації;

- умови праці;

- міжособові стосунки на робочому місці;

- заробітну плату;

- невпевненість в стабільності;

- вплив роботи на особисте життя.

Напевно, найбільш дивним i несподіваним відкриттям, отриманими в результаті проведених Герцбергом досліджень, став той факт, що гроші однозначно були віднесені до розряду гігієнічних чинників, а аж ніяк не мотиваторів. Гроші мають важливе значення для більшості службовців, як через їх купівельної спроможності, так і через статус, який має їх власник. Однак менеджери роблять собі та своїм організаціям погану послугу, коли гроші сприймають як досконалий засіб для задоволення всіх потреб, які можуть виникнути у службовців.

Теорія Герцберга не враховувала впливу багатьох змінних величин на ситуацію. Що може мотивувати однулюдину, не може мотивувати іншу, тобто мотивувати різних людей будуть різні фактори. Згодом вчені дійшли висновку, що для пояснення механізму мотивації необхідно враховувати різноманітні поведінкові аспекти. Це призвело до створення процесуальних теорій мотивації. Основна концепція цих теорій полягає в тому, що поряд 3 урахуванням потреб необхідно брати до уваги те, як людина розподіляє зусилля для досягнення різних цілей і який вид поведінки він вибирає.

Існує безліч різних теорій i моделей мотивації. Серед них можна виділити теорію потреб Абрахама Маслоу, теорію очікувань Віктора Врума, теорію Дугласа МакГрегора, теорію двох факторів Фредеріка Герцберга та інші. Керівникам організацій не варто шукати в цих роботах готових рецептів по мотивування персоналу, але, засвоївши для себе їх основні положення, необхідно виробити для себе свою програму мотивації персоналу. Слід також зрозуміти, що на кожному конкретному підприємстві повинна бути своя специфічна програма, в якій би враховувалися всі особливості діяльності компаніï[6].

У процесі дослідження були виявлені потреби працівників, їх прагнення, задоволення яких сприятиме їх успішній роботі. Слід зазначити, що в ході проведення анкетування було виявлено незадоволеність співробітників одержуваною ними заробітної платою, але багато співробітників показали прагнення до успіху i досягнень. При правильній організації системи заохочень найімовірніше збільшиться рівень продуктивності праці, i як наслідок організація зможе піднятися на вищий рівень розвитку[7].

Висновки 3 дослідження i перспективи, подальший розвиток у даному напрямку.

Економічна ефективність будь-якого виду людської діяльності багато в чому визначається цілями , які переслідуються , 
в їх основі - потреби, інтереси, стимули суб'єктів праці. Методологія їх утворення та функціонування глибоко i всебічно досліджена.

При аналізі проблем організації праці на підприємстві та взаємодії між підрозділами, були запропоновані деякі заходи, щодо координації дій керівника, необхідні для найбільш ефективної мотивації працівників та забезпечення оптимального рівня якості виконання ними роботи, при врахуванні необхідності задоволення їх потреб.

Зроблені висновки не $\epsilon$ остаточними. Вони лише відповідають положенню речей на даний момент часу. Управління організацією i персоналом зокрема - складна і відповідальна робота, i кожен керівник повинен враховувати всі можливі фактори в розробці подібної програми. Саме в цьому запорука успішної роботи співробітників організації, а також ефективної діяльності банку в цілому.

У підсумок слід зазначити, що шлях до ефективного управління персоналом лежить через розуміння його мотивації. Тільки знаючи, що рухає людиною, що спонукає іiі до дій, які мотиви лежать в основі іiі поведінки, можна спробувати розробити ефективну систему форм і методів управління людиною. Для цього необхідно знати, як виникають ті чи інші мотиви, як $\mathrm{i}$ якими способами, мотиви можуть бути приведені в дію, як здійснюється мотивування людей.

\section{Список використаних джерел}

1. Кибанов А.Я., Управление персоналом организации / Под ред. А.Я. Кибанова.-М.: ИНФРА-М, - 2003, с. 483.

2. Кибанов А.Я., Баткаева И.А., Митрофанова Е.А., Ловчева М.В., Мотивация и стимулирование трудовой деятельности. М.: ИНФРА-М, - 2009, с. 524.

3 Макклелланд, Д., Мотивация человека [Текст]: уч. пособие / Д. Макклелланд; пер. с англ. - СПб.: Питер, 2007. - 337 с.

4 Белецкая И.И. Современный механизм формирования конкурентных преимуществ в свете эволюции их теории [Текст]: уч. пособие / И.И. Белецкая. // Прометей. - 2006. - 372с.

5 Офіційний сайт інформаційного порталу «Вікіпедіа» [Електрон. ресурс]. - Режим доступу: - http://uk.wikipedia.org/

6 Кузьмін О.Є. Основи менеджменту: підручник/ О.Є. Кузьмін, О.Г. Мельник. 2-е вид., випр. та допов. - К. : Академвидав,2007. - 464 с.

7 Мазаракі А.А. Менеджмент: теорія і практика : навч. посіб. / А.А. Мазаракі, Г.Є. Мошек, Л.А. Гомба та ін. - К. : Атіка, 2007. - 564 с.

Рецензент д-р економ. наук, професор О.Г.Дейнека

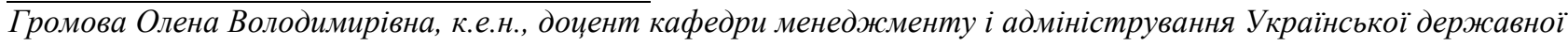
академії залізничного транспорту. Тел. (057) 730-10-46 E-mail: gllo2012@ mail.ru НосикСергій Олександрович, магістрант Tel. (095) 1379990

Gromova Olena Volodumurivna, , d.e.s., lecturer of department of management and administration Ukrainian State Academy of Railway Transport.Tel. (057) 730-10-46 E-mail: gllo2012@mail.ru

Nosik Sergiy, Master's Student Tel. (095) 1379990 